\title{
PENGARUH KOMPENSASI FINANSIAL, LINGKUNGAN KERJA DAN MOTIVASI KERJA TERHADAP KINERJA PEGAWAI PADA KANTOR PDAM KOTA PAYAKUMBUH
}

\author{
Heru Marta Saputra, Riri Mayliza \\ Sekolah Tinggi Ilmu Ekonomi "KBP” \\ ririmayliza@akbpstie.ac.id
}

\begin{abstract}
Effect of Financial Compensation, Work Environment and Work Motivation on Employee Performance in the Regional Water Company (PDAM) Payakumbuh. The principal issues in this study is whether the process of financial compensation, work environment, work motivation influence on the performance of employees at the Regional Water Company (PDAM) Payakumbuh. This study aims to reveal the Financial Compensation Effect, Work Environment and Work Motivation on Employee Performance in the Regional Water Company (PDAM) Payakumbuh. This research is descriptive associative. The population in this study is the employee at the Regional Water Company (PDAM) Payakumbuh totaling 67 people. The sampling technique sampling study is saturated. The questionnaire was used as data collection techniques. Data analysis technique used is descriptive analysis and multiple regression analysis, multicollinearity analysis, analysis heterokedastisistas, normality test and coefficient detereminasi. To test the hypothesis used t test, Test F. Based on the analysis of the influence of financial compensation, work environment and work motivation and employee performance, especially in the Regional Water Company (PDAM) Payakumbuh, it would seem that there is a positive influence and significant correlation between financial compensation, work environment, work motivation on employee performance. Thus the hypothesis is proved.
\end{abstract}

Keywords: financial compensation, work environment, motivation and performance 


\section{PENDAHULUAN}

Masalah sumber daya manusia masih menjadi sorotan dan tumpuan bagi suatu organisasi untuk tetap dapat bertahan di era globalisasi. Sumber daya manusia mempunyai peran utama dalam setiap kegiatan organisasi. Walaupun didukung dengan sarana dan prasarana serta sumber dana yang berlebihan, tetapi tanpa dukungan sumber daya manusia yang handal kegiatan organisasi tidak akan terselesaikan dengan baik.

Pegawai sebagai tenaga kerja merupakan faktor yang sangat penting sebagai suatu pelaksana/penggerak yang menjalankan roda-roda organisasi atau perusahaan. Keberhasilan suatu organisasi tidak hanya ditentukan oleh perangkat dan fasilitas kerja yang lengkap, tetapi juga ditentukan oleh kualitas manusia yang mengerjakannya. Disamping itu harus memiliki jumlah tenaga kerja yang mencukupi, organisasi pun harus memberikan pegawainya dengan kompensasi dengan proporsi yang wajar, lingkungan kerja yang bagus dan motivasi kerja yang tinggi.

Perusahaan Daerah Air Minum (PDAM), merupakan salah satu BUMN yang bergerak dalam bidang sarana penyediaan air bersih yang diawasi dan dimonitori oleh aparat eksekutif maupun legislatif daerah. PDAM sebagai perusahaan daerah yang diberi tanggung jawab untuk mengembangkan dan mengelola system penyediaan air bersih serta melayani semua kelompok kunsumen dengan harga yang terjangkau. PDAM bertanggung jawab pada operasional sehari-hari, perencanaan aktivitas, persiapan dan implementasi proyek, serta bernegosiasi dengan pihak swasta untuk mengembangkan layanan kepada masyarakat. Keberhasilan dan kelangsungan hidup perusahaan ini sangat tergantung pada sejauh mana para pegawai dapat memberikan pelayanan dalam kualitas yang sesuai dengan harapan dan keinginan para pengguna jasa. Dalam menghadapi tuntutan masyarakat akan peningkatan pelayanan baik kualitas maupun kuantitasnya dan untuk tetap survive maka setiap kantor diusahakan untuk tidak berbuat salah. Untuk itu dalam membentuk suatu pelayanan secara utuh dan berkualitas, maka dibutuhkan kinerja yang baik. .

Didalam upaya meningkatkan kinerja karyawan, usaha yang dilakukan perusahaan tidak akan lepas dari berbagai faktor, diantaranya kompensasi yang diberikan kepada karyawan dan juga motivasi yang ada dalam diri karyawan. Tidak hanya faktor keterampilan, kemampuan dan penguasaan kerja karyawan yang terus dikembangkan oleh perusahaan untuk meningkatkan kinerja karyawan. Akan tetapi perusahaan harus memperhatikan pula faktor pemberian kompensasi sebagai salah satu motif bagi karyawan untuk bekerja. Pemberian kompensasi bagi karyawan merupakan kewajiban bagi perusahaan yang harus dipenuhi tepat waktu secara adil dan berdasarkan hasil kerja. Menurut Simamora kompensasi terdiri dari Kompensasi Finansial (bayaran pokok, bayaran prestasi, bayaran insentif, bayaran tertangguh, program perlindungan, bayaran diluar jam kerja, fasilitas) dan Kompensasi Nonfinansial (pekerjaan dan lingkungan kerja).

Di samping faktor kompensasi, faktor lain yang dapat mempengaruhi kinerja pegawai adalah lingkungan kerja. Menurut Sedarmayanti (2001:1) mendefinisikan lingkungan kerja sebagai berikut : "Lingkungan kerja adalah keseluruhan alat perkakas dan bahan yang dihadapi lingkungan sekitarnya di 
mana seseorang bekerja, metode kerjanya, serta pengaturan kerjanya baik sebagai perseorangan maupun sebagai kelompok". Lingkungan kerja ini meliputi tempat kerja, fasilitas dan alat bantu pekerjaan, kebersihan pencahayaan, ketenangan termasuk juga hubungan kerja antara orang-orang yang ada ditempat tersebut. Lingkungan kerja dalam perusahaan sangat penting dan besar pengaruhnya terhadap pekerja dalam melakukan aktivitasnya. Dengan lingkungan kerja yang baik, maka pekerja dapat merasakan rangsangan untuk menjalankan tugas-tugas yang diberikan, untuk itu hendaknya perusahaan menciptakan suatu lingkungan kerja yang dapat menyenangkan diri pegawai.

Rumusan Masalah

Berdasarkan uraian diatas, maka perumusan masalah pada penelitian ini adalah sebagai berikut : a) Bagaimana Kompensasi Finansial berpengaruh terhadap Kinerja Pegawai Pegawai pada Perusahaan Daerah Air Minum (PDAM) kota Payakumbuh? b) Bagaimana Lingkungan Kerja berpengaruh terhadap Kinerja Pegawai Pegawai pada Perusahaan Daerah Air Minum (PDAM) kota Payakumbuh? c) Bagaimana Motivasi kerja berpengaruh terhadap Kinerja Pegawai pada Perusahaan Daerah Air Minum (PDAM) kota Payakumbuh?

Tujuan Penelitian

Adapun tujuan yang akan dicapai dari penelitian ini adalah untuk mengetahui: a) Pengaruh Kompensasi Finansial terhadap Kinerja Pegawai pada Perusahaan Daerah Air Minum (PDAM) Kota Payakumbuh. b) Pengaruh Lingkungan kerja terhadap kinerja Pegawai pada Perusahaan Daerah Air Minum (PDAM) Kota Payakumbuh. c) Pengaruh Motivasi kerja terhadap Kinerja Pegawai pada Perusahaan Daerah Air Minum (PDAM) Kota Payakumbuh.

\section{TINJAUAN PUSTAKA}

Kompensasi merupakan imbalan jasa atau balas jasa yang diberikan oleh organisasi kepada para pegawai karena pegawai tersebut telah memberikan sumbangan tenaga dan pikiran demi kemajuan organisasi guna mencapai tujuan yang telah ditetapkan. Menurut Hasibuan ( 2012:118) kompensasi merupakan semua pendapatan yang berbentuk uang, barang, langsung atau tidak langsung yang diterima karyawan sebagai imbalan atas jasa yang diberikan kepada perusahaan. Menurut Mondy (2008:5) menyatakan bahwa kompensasi finansial yaitu yang diwujudkan dengan sejumlah uang kartal kepada karyawan yang bersangkutan.

Widodo (2004:23) mengatakan bahwa pemberian kompensasi kerja sangat penting bagi karyawan, karena besar kecilnya kompensasi merupakan ukuran terhadap prestasi kerja karyawan, maka apabila sistem kompensasi yang diberikan perusahaan cukup adil untuk karyawan, akan mendorong karyawan untuk lebih baik dalam melakukan pekerjaannya dan lebih bertanggung jawab atas masingmasing tugas yang diberikan perusahaan.

Menurut Hasibuan (2012:121), tujuan pemberian kompensasi (balas jasa) antara lain adalah: a) Ikatan Kerja Sama, dengan pemberian kompensasi terjalinlah ikatan kerja sama formal antara majikan dengankaryawan. Karyawan harus mengerjakan tugas-tugasnya dengan baik, sedangkan pengusaha/majikan wajib membayar kompensasi sesuai dengan perjanjian yang disepakati. b) 
Kepuasan Kerja, dengan balas jasa, karyawan akan dapat memenuhi kebutuhankebutuhan fisik, status sosial dan egoistiknya sehingga memperoleh kepuasan kerja dari jabatannya. c) Pengadaan Efektif, jika program kompensasi ditetapkan cukup besar, pengadaan karyawan yang qualified untuk perusahaan akan lebih mudah. d) Motivasi, jika balas jasa yang diberikan cukup besar, manajer akan mudah memotivasi bawahannya. e) Stabilitas Karyawan, dengan program kompensasi atas prinsip adil dan layak serta eksternal konsistensi yang kompentatif maka stabilitas karyawan lebih terjamin karena turn-over relatif kecil. f) Disiplin, dengan pemberian balas jasa yang cukup besar maka disiplin karyawan semakin baik. Mereka akan menyadari serta mentaati peraturanperaturan yang berlaku. g) Pengaruh Serikat Buruh, dengan program kompensasi yang baik pengaruh serikat buruh dapat dihindarkan dan karyawan akan berkosentrasi pada pekerjaannya. h) Pengaruh Pemerintah, jika program kompensasi sesuai dengan undang-undang perburuhan yang berlaku (seperti batas upah minimum) maka intervensi pemerintah dapat dihindarkan.

Adapun indikator dari kompensasi finansial yang peneliti gunakan dalam penelitian ini berdasarkan pendapat Hasibuan (2000) dalam Raissa (2013:34) yaitu: a) Kecukupan, berarti cukup dalam perihal. Dalam segi kebutuhan karyawan harus terpenuhi. Untuk memenuhi kebutuhan, karyawan akan bekerja dan akhirnya akan mendapatkan imbalan atau jasa atas hasil kerjanya. Untuk itu kompensasi yang diterima karyawan harus cukup dan karyawan bisa memenuhi kebutuhannya sehari-hari. b) Keadilan, kompensasi harus memenuhi rasa keadilan bagi setiap karyawan. Bagi para pengelola sistem kompensasi harus tahu bagaimana sistem kompensasi mampu menjaga rasa keadilan. Agar terjadi keseimbangan itu maka para pengelola kompensasi berupaya melakukan maintenance terhadap sistem dan besaran nilai kompensasi yang ada di dalam perusahaan. c) Kesesuaian dengan kinerja, pegawai dalam bekerja tentunya menerima kompensasi yang sesuai dengan kinerjanya. Pemberian kompensasi karyawan juga harus sesuai dengan peraturan yang berlaku, serta selalu memperhatikan standar dan biaya hidup minimal.Tanpa mengesampingkan asas, adil, layak dan wajar, agar kompensasi yang diberikan kepada masing-masing karyawan sesuai dengan kinerjanya.

Menurut Sukanto dan Indriyo (2000:151) dalam Ginanjar (2012:3) lingkungan kerja merupakan segala sesuatu yang ada disekitar pekerja dan dapat mempengaruhi dalam bekerja meliputi pengaturan penerangan, pengontrolan suara gaduh, pengaturan kebersihan tempat kerja dan pengaturan keamanan tempat kerja.Menurut pendapat Rivai (2004: 165) lingkungan kerja adalah keseluruhan sarana dan prasarana yang ada disekitar karyawan yang sedang melakukan pekerjaan itu sendiri. Lingkungan kerja ini akan meliputi tempat kerja, fasilitas dan alat bantu pekerjaan, kebersihan, pencahayaan dan ketenangan termasuk juga hubungan antara orang-orang yang ada ditempat tersebut.

Berdasarkan Sedarmayanti (2001) yang telah dipaparkan di atas maka yang dapat dijadikan indikator lingkungan kerja yaitu, a) Penerangan, b) Suhu udara, c) Suara bising, d) Penggunaan warna, e) Ruang gerak yang diperlukan, f) Keamanan kerja dan g) Hubungan karyawan. 
Motivasi adalah daya pendorong yang mengakibatkan seseorang anggota organisasi mau dan rela untuk menggerakkan kemampuan dalam bentuk keahlian atau keterampilan tenaga dan waktunya untuk menyelenggarakan berbagai kegiatan yang menjadi tanggung jawab dalam menunaikan kewajibannya dalam rangka mencapai tujuan dan sasaran organisasi yang telah ditentukan sebelumnya".

Dari kutipan di atas dan dikaitkan dengan ekstensi Pegawai bahwa motivasi berkaitan langsung dengan motivasinya untuk mencapai tujuan (visi dan misi) organisasi dan usaha seorang pimpinan untuk membuat pegawainya untuk termotivasi dalam berbagai hal.Dengan demikian jelas bahwa tanpa motivasi maka pegawai kurang mampu dalam mencapai tujuan organisasinya. Menurut Winardi (dalam Indriani, 2005:12) menyatakan bahwa motivasi adalah dorongan yang membuat seseorang bertindak atau berperilaku dalam cara-cara tertentu.

Robbins (2007:230) menerangkan teori motivasi McClelland berfokus pada tiga kebutuhan dan penulis jadikan sebagai indikator motivasi kerja yaitu: a) Kebutuhan akan prestasi, yaitu dorongan untuk menggungguli, berprestasi berdasar seperangkat standar, berusaha agar sukses. b) Kebutuhan kekuasaaan, kebutuhan untuk membuat orang lain berprilaku dalam suatu cara yang orang itu (tanpa dipaksa) tidak akan berprilaku demikian. c) Kebutuhan akan kelompok pertemanan, hasrat akan hubungan antar pribadi yang ramah dan akrab.

Kinerja merupakan suatu istilah secara umum yang digunakan untuk sebagian atau seluruh tindakan atau aktivitas dari suatu organisasi pada suatu periode dengan referensi pada sejumlah standar seperti biaya-biaya masa lalu yang diproyeksikan, dengan dasar efisiensi pertanggungjawaban atau akuntabilitas manajemen dan semacamnya (Srimindarti,2004).

Menurut Rivai (2009:548) menyatakan kinerja merupakan suatu fungsi dari motivasi dan kemampuan.Untuk menyelesaikan tugas atau pekerjaan seseorang sepatutnya memiliki derajat kesediaan dan tingkat kemampuan tertentu. Kesediaan dan keterampilan seseorang tidaklah cukup efektif untuk mengerjakan sesuatu tanpa pemahaman yang jelas tentang apa yang dikerjakan dan bagaimana mengerjakannya. Kinerja merupakan perilaku nyata yang di tampilkan setiap orang sebagai prestasi kerja yang dihasilkan oleh karyawan sesuai dengan perannya dalam upaya perusahaan untuk mencapai tujuannya. Menurut Atmosoeprapto, dalam Hessel (2005 : 181 ) mengemukakan bahwa kinerja organisasi dipengaruhi oleh faktor internal dan faktor eksternal, secara lebih lanjut kedua faktor tersebut diuraikan sebagai berikut: Faktor eksternal, yang terdiri dari : a) Faktor politik, yaitu hal yang berhubungan dengan keseimbangan kekuasaan Negara yang berpengaruh pada keamanan dan ketertiban, yang akan mempengaruhi ketenangan organisasi untuk berkarya secara maksimal. b) Faktor ekonomi, yaitu tingkat perkembangan ekonomi yang berpengaruh pada tingkat pendapatan masyarakat sebagai daya beli untuk menggerakkan sektor-sektor lainya sebagai suatu system ekonomi yang lebih besar. c) Faktor sosial, yaitu orientasi nilai yang berkembang di masyarakat, yang mempengaruhi pandangan mereka terhadap etos kerja yang dibutuhkan bagi peningkatan kinerja organisasi. Faktor internal, yang terdiri dari : a) Tujuan organisasi, yaitu apa yang ingin dicapai dan apa yang ingin diproduksi oleh suatu organisasi. b) Struktur 
organisasi, sebagai hasil desain antara fungsi yang akan dijalankan oleh unit organisasi dengan struktur formal yang ada. c) Sumber Daya manusia, yaitu kualitas dan pengelolaan anggota organisasi sebagai pengerak jalanya organisasi secara keseluruhan. d) Budaya Organisasi, yaitu gaya dan identitas suatu organisasi dalam pola kerja.

\section{METODE PENELITIAN}

\section{Populasi dan Sampel}

Menurut Siregar (2010:144) "populasi berasal dari bahasa Inggris yaitu population yang berarti jumlah penduduk. Dalam metode penelitian, kata populasi amat populer dipakai untuk menyebutkan serumpun/sekelompok objek yang menjadi sasaran penelitian".. Dalam penelitian ini yang akan menjadi populasi adalah seluruh pegawai pada Perusahaan Daerah Air Minum (PDAM) Kota Payakumbuh yang berjumlah 67 orang.

Sampel dalam penelitian ini adalah total sampling dimana seluruh populasi yang ada menjadi sampel penelitian. Arikunto (2006:103) mengemukakan jika populasi kurang dari 100 orang maka penentuan jumlah sampel ditentukan secara total sampling. Jadi jumlah sampel pada penelitian ini adalah sebanyak 67 orang.

\section{Definisi Operasional}

\section{Kinerja Pegawai}

Kinerja pegawai yang dimaksud dalam penelitian ini adalah suatu proses pekerjaan dan hasil/prestasi kerja yang dicapai Pegawai Perusahaan Daerah Air Minum (PDAM) Kota Payakumbuh dalam melaksanakan suatu pekerjaan sesuai dengan tugas pokok, fungsi dan tanggung jawabnya terhadap tugasnya untuk mencapai tujuan yang diharapkan yang dapat diukur baik secara kuantitatif maupun kualitatif. Indikator kinerja pegawai yang digunakan adalah a. Kualitas Kerja, b. Ketepatan Waktu, c. Inisiatif d. Kemampuan dan e. Komunikasi.

\section{Kompensasi Finansial}

Kompensasi merupakan imbalan jasa atau balas jasa yang diberikan oleh organisasi kepada para pegawai karena pegawai tersebut telah memberikan sumbangan tenaga dan pikiran demi kemajuan organisasi guna mencapai tujuan yang telah ditetapkan. Kompensasi finansial merupakan imbalan jasa atau balas jasa yang diberikan oleh organisasi kepada para pegawai berupa bayaran. Adapun yang menjadi indikator kompensasi finansial dalam penelitian ini adalah: a) Kecukupan b) Keadilan, c) Kesesuaian dengan kinerja

\section{Lingkungan Kerja}

Lingkungan kerja yang dimaksud dalam penelitian ini adalah lingkungan dimana tempat karyawan melakukan aktivitas atau pekerjaan yang dapat mempengaruhi karyawan dalam bekerja.

Dengan indikator sebagai berikut yaitu a) Penerangan, b) Suhu udara, c) Suara bising, d) Penggunaan warna, e) Ruang gerak yang diperlukan f) Keamanan kerja dan g) Hubungan karyawan.

\section{Motivasi Kerja}

Motivasi kerja pegawai kantor adalah daya pendorong yang mengakibatkan seorang pegawai mau dan rela untuk menggerakkan kemampuan dalam bentuk keahlian, tenaga dan waktunya untuk menyelenggarakan berbagai kegiatan yang 
menjadi tanggung jawab dalam menunaikan kewajiban dan tugasnya dalam rangka mencapai tujuan dan sasaran kantor. Motivasi dan daya pendorong tersebut diantaranya adalah dalam tanggung jawab, prestasi yang dicapai, pengembangan diri serta kemandirian bertindak.

\section{Teknis Analisis Data}

Variabel mengenai pengaruh Kompensasi Finansial, Lingkungan Kerja dan motivasi kerja terhadap kinerja pegawai pada Perusahaan Daerah Air Minum (PDAM). Adapun gambaran analisis deskriptif kompensasi Finansial, Lingkungan Kerja, Motivasi Kerja, Terhadap Kinerja Pegawai Pada Perusahaan Daerah Air Minum (PDAM) Kota Payakumbuh dapat dilihat pada tabel dibawah ini :

\section{Tabel 1}

Analisis Deskriptif Kompensasi Finansial, Lingkungan Kerja, Motivasi Kerja, Terhadap Kinerja Pegawai Pada Perusahaan Daerah Air Minum (PDAM) Kota Payakumbuh.

\begin{tabular}{|c|c|c|c|c|}
\hline No & Variabel & Mean (Rerata) & TCR (\%) & Kriteria \\
\hline 1 & Kompensasi Finansial & 4,35 & 86,95 & Baik \\
\hline 2 & Lingkungan Kerja & 4,34 & 86,89 & Baik \\
\hline 3 & Motivasi Kerja & 4,39 & 87,85 & Baik \\
\hline 4 & Kinerja & 4,36 & 87,19 & Baik \\
\hline
\end{tabular}

Sumber : Pengolahan Data Primer 2017

Berdasarkan tabel 1 dapat diketahui bahwa dari 4 variabel yaitu kompensasi finansial, lingkungan kerja, dan motivasi kerja terhadap kinerja. Hal ini terlihat dari variabel kompensasi finansial dengan rata-rata 4,35 dan TCR 86,95 . Lingkungan kerja dengan rata-rata 4,34 dan 86,89. Motivasi kerja dengan rata-rata 4,39 dan TCR 87,85 . Selain itu pada variabel kinerja karyawan dengan rata-rata 4.36 dan TCR 87,19 .

Tabel 2

Uji Normalitas

One-Sample Kolmogorov-Smirnov Test

\begin{tabular}{|c|c|c|c|c|c|}
\hline & $\mathrm{x} 1$ & $\mathrm{x} 2$ & $\mathrm{x} 3$ & $\mathrm{Y}$ \\
\hline & $\mathrm{N}$ & 67 & 67 & 67 & 67 \\
\hline Normal & Mean & 47.82 & 52.13 & 43.93 & 47.96 \\
\hline $\begin{array}{l}\text { Parame } \\
\text { ters }^{a}\end{array}$ & Std. Deviation & 4.355 & 4.985 & 3.336 & 4.343 \\
\hline Most & Absolute & .085 & .065 & .091 & .095 \\
\hline extrem & Positive & .085 & .064 & .091 & .095 \\
\hline \begin{tabular}{|l} 
Differen \\
ces
\end{tabular} & Negative & -.071 & -.065 & -.068 & -.086 \\
\hline Kolm & orov-Smirnov Z & .693 & .533 & .746 & .779 \\
\hline Asyn & Sig. (2-tailed) & .722 & .939 & .633 & .579 \\
\hline
\end{tabular}

Sumber : Hasil Olahan Data Primer 2017

Hasil pengolahn SPSS 16 di dapat nilai kolmogorof smirnov >0,05, yaitu 0,579 untuk variabel Y; 0,722 untuk variabel X1; 0,939 untuk variabel X2;0,633 untuk variabel X3. Dengan demikian dapat dikatakan bahwa data berdistribusi 
secara normal. Nilai kolmogorof smirnov untuk masing-masing variabel dapat dilihat pada tabel 2

Tabel 3

Tabel Uji Multikolineritas Coefficients

\begin{tabular}{|c|c|c|}
\hline \multirow{2}{*}{ Model } & \multicolumn{2}{|c|}{ Collinearity Statistics } \\
\cline { 2 - 3 } & Tolerance & VIF \\
\hline Constant & & 1.324 \\
\hline X1 & 755 & 1.452 \\
\hline X2 & 689 & 1.271 \\
\hline
\end{tabular}

Sumber: Pengolahan Data Primer 2017 a.Dependent Varible:y

Berdasarkan tabel 3 menunjukkan bahwa variabel kompensasi finansial (X1) dengan nilan VIF 1.324, variabel lingkungan kerja (X2) dengan nilai VIF 1.452, dan variabel motivasi kerja (X3) dengan nilai VIF 1.271, adalah nilai VIF yang kecil dari 5. Untuk nilai tolerance dari penelitian ini untuk variabel kompensasi finansial (X1) adalah 0,755, variabel lingkungan kerja (X2) adalah 0,689, dan untuk variabel motivasi kerja (X3) adalah 0,787 merupakan nilai yang mendakati 1. Dengan demikian dapat dikatakan bahwa tidak dapat korelasi variabel-variabel bebas antara satu dengan yang lainnya, atau bebas multikolinieritas.

Tabel 4

Uji Heterokedastisitas Coefficients $^{\mathrm{a}}$

\begin{tabular}{|c|c|c|c|c|c|c|}
\hline & \multirow[b]{2}{*}{ Model } & \multicolumn{2}{|c|}{$\begin{array}{l}\text { Unstandardized } \\
\text { Coefficients }\end{array}$} & \multirow{2}{*}{$\begin{array}{c}\text { Standardized } \\
\text { Coefficients }\end{array}$} & \multirow[b]{2}{*}{$\mathrm{t}$} & \multirow[b]{2}{*}{ Sig. } \\
\hline & & B & Std. Error & & & \\
\hline \multirow[t]{4}{*}{1} & (Constant) & 8.524 & 6.523 & & 1.307 & .196 \\
\hline & $\mathrm{x} 1$ & .254 & .114 & .255 & 2.239 & .029 \\
\hline & $\mathrm{x} 2$ & .247 & .104 & .283 & 2.373 & .021 \\
\hline & x3 & .328 & .145 & .252 & 2.259 & .027 \\
\hline
\end{tabular}

a. Dependent Variable: $\mathrm{Y}$

Sumber : Data Pengloahan 2017

Berdasarkan tabel 4. hasil uji heterokedastisitas melalui Uji Glejser dapat dilihat bahwa signifikansi pada masing-masing variabel bernilai lebih dari 0,05 tetapi pada variabel lingkungan kerja nilai signifikansi dibawah dari 0.05. Jadi dapat dikatakan bahwa hal ini menunjukkan tidak terjadi heterokedastisitas dalam model regresi pada penelitian ini, dan variabel-variabel independen dapat dinyatakan tidak mengalami heterokedastisitas. 
Tabel 5

Hasil Uji Analisis Regresi Berganda

Coefficients $^{\mathrm{a}}$

\begin{tabular}{|c|c|c|c|c|c|c|}
\hline & \multirow[b]{2}{*}{ Model } & \multicolumn{2}{|c|}{$\begin{array}{l}\text { Unstandardized } \\
\text { Coefficients }\end{array}$} & \multirow{2}{*}{$\begin{array}{l}\text { Standardized } \\
\text { Coefficients } \\
\text { Beta }\end{array}$} & \multirow[b]{2}{*}{$\mathrm{t}$} & \multirow[b]{2}{*}{ Sig. } \\
\hline & & B & Std. Error & & & \\
\hline \multirow[t]{4}{*}{1} & (Constant) & 8.524 & 6.523 & & 1.307 & .196 \\
\hline & $\mathrm{x} 1$ & .254 & .114 & .255 & 2.239 & .029 \\
\hline & $\mathrm{x} 2$ & .247 & .104 & .283 & 2.373 & .021 \\
\hline & $\mathrm{x} 3$ & .328 & .145 & .252 & 2.259 & .027 \\
\hline
\end{tabular}

a. Dependent Variable: $Y$

Sumber : Hasil Olahan Data Primer 2017

Dari tabel di atas dapat diperoleh persamaan regresi linear berganda sebagai berikut :

$$
\begin{aligned}
& Y=a+b_{1} X_{1}+b_{2} X_{2}+b_{3} X_{3} \\
& Y=8,524+0,254+0,247+0,328
\end{aligned}
$$

Dari persamaan diatas dapat diketahui nilai konstanta yang diperoleh sebesar 8,524. Hal ini berarti bahwa jika variabel independen kompensasi finansial, lingkungan kerja, dan motivasi kerja tidak dipertimbangkan maka besarnya kinerja 8,524. Nilai koefisien regresi berganda variabel kompensasi finansial (X1) sebesar 0,254 dengan sig 0,029 < 0,05. Hal ini berarti bahwa tingkat kompensasi financial berpengaruh signifikan terhadap kinerja karyawan.

Sedangkan nilai koefisien regresi berganda variabel lingkungan (X2) sebesar 0,247 dengan sig 0,021 $<0,05$, berarti lingkungan kerja berpengaruh signifikan terhadap kinerja karyawan. Nilai koefisien regresi berganda variabel motivasi kerja (X3) sebesar 0,328 dengan sig 0,027<0,05 berarti motivasi kerja berpengaruh signifikan terhadap kinerja.

\section{HASIL PENELITIAN}

\section{Pengujian Hipotesis}

Tabel 6

Uji t

\begin{tabular}{|c|c|c|c|c|c|c|}
\hline & \multirow[b]{2}{*}{ Model } & \multicolumn{2}{|c|}{$\begin{array}{l}\text { Unstandardized } \\
\text { Coefficients }\end{array}$} & \multirow{2}{*}{$\begin{array}{c}\begin{array}{c}\text { Standardized } \\
\text { Coefficients }\end{array} \\
\text { Beta }\end{array}$} & \multirow[b]{2}{*}{$\mathrm{t}$} & \multirow[b]{2}{*}{ Sig. } \\
\hline & & B & Std. Error & & & \\
\hline \multirow[t]{4}{*}{1} & (Constant) & 8.524 & 6.523 & & 1.307 & .196 \\
\hline & $\mathrm{x} 1$ & .254 & .114 & .255 & 2.239 & .029 \\
\hline & $\mathrm{x} 2$ & .247 & .104 & .283 & 2.373 & .021 \\
\hline & $\mathrm{x} 3$ & .328 & .145 & .252 & 2.259 & .027 \\
\hline
\end{tabular}

Coefficients $^{\mathrm{a}}$

a. Dependent Variable: $\mathrm{Y}$

Sumber : Hasil Olahan Data Primer 2017 
Berdasarkan tabel 6 dapat dilihat pengaruh masing-masing variabel bebas (kompensasi finansial, lingkungan kerja, motivasi kerja) terhadap variabel terikat (kinerja karyawan) secara parsial adalah :

Pengujian Variabel Kompensasi Finansial (X1)

Hasil Pengujian SPSS untuk variabel Kompensasi Finansial (X1) terhadap Kinerja Karyawan (Y) diperoleh nilai $t_{\text {hitung }}$ adalah 2,239 $>t_{\text {tabel }}$ 1,996008 dengan demikian dapat dikatakan bahwa terdapat pengaruh nyata antara variabel kompensasi finansial dengan kinerja karyawan. Disamping itu Sig 0,029 karena nilai Sig 0,029 < 0,05 dapat disimpulkan bahwa kompensasi finansial signifikan terhadap kinerja karyawan, sebab nilai Sig $<0,05$ sehingga dapat dikatakan ada pengaruh yang positif dan signifikan antara kompensasi finansial dengan kinerja karyawan.

Pengujian Variabel Lingkungan Kerja (X2)

Hasil pengujian SPSS untuk variabel Lingkungan Kerja (X2) terhadap Kinerja Karyawan (Y) diperoleh $t_{\text {hitung }}$ adalah 2,373 $>t_{\text {tabel }}$ 1,996008 dengan demikian dapat dikatakan bahwa terdapat pengaruh nyata antara variabel lingkungan kerja terhadap kinerja karyawan. Disamping itu Sig 0,021 dapat disimpulkan bahwa lingkungan kerja signifikan terhadap kinerja karyawan, sebab nilai Sig sig 0,021 $<0,05$ sehingga dapat dikatakan ada pengaruh yang positif dan signifikana antara lingkungan kerja dengan kinerja karyawan.

Pengujian Variabel Motivasi Kerja (X3)

Hasil pengujian dengan SPSS untuk variabel Motivasi kerja (X3) terhadap Kinerja Karyawan (Y) diperoleh nilai $t_{\text {hitung }}$ adalah 2,259 adalah 2,259 $>t_{\text {tabel }}$ 1,996008 dengan demikian dapat dikatakan bahwa terdapat pengaruh nyata antara variabel motivasi kerja dengan kinerja karyawan. Disamping itu Sig 0,027 dapat disimpulkan bahwa motivasi kerja signifikan terhadap kinerja karyawan, sebab nilai sig $0,027<0,05$ sehingga dapat dikatakan ada pengaruh yang positif dan signifikan antara motivasi kerja dengan kinerja karyawan.

\section{Tabel 7}

Uji F

ANOVA ${ }^{b}$

\begin{tabular}{|c|c|c|c|c|c|}
\hline Model & $\begin{array}{l}\text { Sum of } \\
\text { Squares }\end{array}$ & $\mathrm{df}$ & Mean Square & $\mathrm{F}$ & Sig. \\
\hline 1 Regression & 476.478 & 3 & 158.826 & 13.022 & $.000^{\mathrm{a}}$ \\
\hline Residual & 768.388 & 63 & 12.197 & & \\
\hline Total & 1244.866 & 66 & & & \\
\hline
\end{tabular}

a. Predictors: (Constant), X3, X1, X2

b. Dependent Variable: Y

\section{Sumber : Hasil Pengolahan Data 2017}

Berdasarkan hasil penelitian tabel 7 menunjukkan nilai $F_{\text {hitung }}$ sebesar 13,022 dan nilai Sig pada tabel anova $0,000^{\mathrm{a}}$. Nilai $\mathrm{F}_{\text {hitung }}$ tersebut kita bandingkan dengan $F_{\text {tabel }} 2,750541$ yang artinya $\mathrm{Ha}$ atau hipotesis alternative yang digunakan 
diterima sehingga variabel kompensasi finansial, lingkungan kerja, dan motivasi kerja berpengaruh signifikan terhadap kinerja karyawan pada Perusahaan Daerah Air Minum (PDAM) Kota Payakumbuh.

Tabel 8

Koefisien Determinasi $\mathbf{R}^{2}$

Model Summary ${ }^{\text {b }}$

\begin{tabular}{|c|c|c|c|c|c|c|c|c|c|}
\hline \multirow[b]{2}{*}{ Model } & \multirow[b]{2}{*}{$\mathrm{R}$} & \multirow[b]{2}{*}{$\begin{array}{c}\mathrm{R} \\
\text { Square }\end{array}$} & \multirow[b]{2}{*}{$\begin{array}{l}\text { Adjusted } \\
\text { R Square }\end{array}$} & \multirow[b]{2}{*}{$\begin{array}{l}\text { Std. Error of } \\
\text { the Estimate }\end{array}$} & \multicolumn{5}{|c|}{ Change Statistics } \\
\hline & & & & & $\begin{array}{l}\text { R Square } \\
\text { Change }\end{array}$ & $\begin{array}{c}\mathrm{F} \\
\text { Change }\end{array}$ & df1 & df2 & Sig. F Change \\
\hline 1 & $.619^{\mathrm{a}}$ & .383 & .353 & 3.492 & .383 & 13.022 & 3 & 63 & .000 \\
\hline
\end{tabular}

a. Predictors: (Constant), X3, X1, X2

b. Dependent Variable: Y

Sumber : Hasil Pengolahan Data 2017

Nilai $R$ Square pada tabel 8 adalah sebesar 0,383 artinya $38,3 \%$ hal ini berarti variasi variabel dependen yang dapat dijelaskan oleh varaiabel independen adalah sebesar $38,3 \%$, sedangkan sisanya $61,7 \%$ dijelaskan oleh variabel lainnya yang tidak dimasukkan dalam model regresi dalam penelitian ini. Sehingga dapat disimpulkan bahwa kompensasi finansial, lingkungan kerja dan motivasi berpengaruh sebesar 38,3\% terhadap kinerja karyawan, sedangkan sisanya sebesar $61,7 \%$ dipengaruhi oleh variabel lain yang tidak diteliti.

\section{KESIMPULAN DAN SARAN Kesimpulan}

Penelitian ini bertujuan untuk mengungkapkan pengaruh kompensasi finansial, lingkungan kerja dan motivasi kerja terhadap kinerja pegawai pada Perusahaan Daerah Air Minum (PDAM) Kota Payakumbuh. Berdasarkan hasil penelitian ini dan pembahasan maka dapat ditarik kesimpulan sebagai berikut: a) Kompensasi finansial, lingkungan kerja dan motivasi kerja berpengaruh positif dan signifikan terhadap kinerja pegawai pada Perusahaan Daerah Air Minum (PDAM) Kota Payakumbuh. Artinya jika kompensasi finansial yang diterima pegawai sesuai serta lingkungan kerja pegawai yang kondusif dan motivasi kerja pegawai tinggi maka kinerja pegawai juga akan meningkat. b) Kompensasi finansial berpengaruh signifikan terhadap kinerja pegawai pada Perusahaan Daerah Air Minum (PDAM) Kota Payakumbuh secara langsung maupun tidak langsung, namun pengaruh langsung lebih dominan dibandingkan pengaruh secara tidak langsung. Hal ini menunjukkan bahwa semakin sesuai kompensasi finansial maka secara langsung akan membuat kinerja pegawai lebih maksimal dibandingkan pengaruh tidak langsung melalui motivasi kerja. Dengan demikian kompensasi finansial yang diberikan pegawai perlu disesuaikan agar kinerja pegawai meningkat dan bekerja secara maksimal. c) Lingkungan kerja berpengaruh signifikan terhadap kinerja karyawan pada Perusahaan Daerah Air Minum Kota Payakumbuh secara langsung maupun tidak langsung, namun pengaruh langsung lebih dominan dibandingkan pengaruh secara tidak langsung. Hal ini menunjukkan bahwa semakin kondusif lingkungan kerja maka secara langsung akan membuat kinerja pegawai meningkat dibandingkan pengaruh tidak langsung melalui motivasi kerja. Dengan demikian lingkungan kerja yang 
diberikan pegawai lebih kondusif agar kinerja pegawai meningkat dan bekerja secara maksimal. d) Motivasi kerja berpengaruh signifikan terhadap kinerja karyawan pada Perusahaan Daerah Air Minum Kota Payakumbuh secara langsung maupun tidak langsunag. Hal ini menunjukkan bahwa motivasi kerja pegawai meningkat maka kinerja pegawai meningkat secara maksimal.

\section{Saran}

Berdasarkan penelitian yang dilakukan penulis, maka untuk meningkatkan kinerja pegawai pada Perusahaan Daerah Air Minum (PDAM) Kota Payakumbuh penulis dapat memberikan saran sebagai berikut: a) Penelitian ini memperlihatkan bahwa kinerja pegawai dalam bekerja berkategori cukup baik. Artinya masih kurang optimal pegawai dalam melakukan kinerja dan perlu ditingkatkan agar kinerja pegawai menjadi lebih baik. Dilihat dari indikator inisiatif dengan item pernyataan para pegawai masih ada melakukan tugas dan tanggung jawabnya tidak sesuai dengan uraian kerja serta kurang mengatur strategi dalam menyelesaikan pekerjaan agar hasilnya efektif. Maka disarankan kepada pegawai pada Perusahaan Daerah Air Minum (PDAM) Kota Payakumbuh untuk dapat meningkatkan kinerja mereka dalam bekerja, dengan cara mengikuti uraian pekerjaan yang sudah ada serta mengatur strategi atau membuat pencapaian target untuk karir atau sebagainya sehingga eksistensi mereka pada pekerjaan akan meningkat. b) Disarankan kepada Kepala Perusahaan Daerah Air Minum (PDAM) Kota Payakumbuh d agar lebih memperhatikan kompensasi finansial dan lingkungan kerja pegawai karena dilihat dari hasil pengaruh langsung yang lebih besar dari pada pengaruh tidak langsung. Untuk itu agar para pegawai diberi kompensasi finansial yang sesuai dengan kinerja pegawai serta lingkungan kerja yang kondusif. Dan kepada pegawai dapat meningkatkan keterampilan, kemampuan serta kesesuaian kerja sehingga dapat meningkatkan kinerja dalam melaksanakan tugas c) Sebaiknya meneliti faktor-faktor lain yang mempengaruhi kinerja pegawai pada Perusahaan Daerah Air Minum (PDAM) Kota Payakumbuh, karena masih banyak faktor lain yang mempunyai pengaruh yang lebih besar.

\section{DAFTAR PUSTAKA}

Aldi, Y., \& Susanti, F. (2019). Pengaruh Stress Kerja Dan Motivasi Kerja Terhadap Prestasi Kerja Karyawan Pada PT. Frisian Flag Indonesia Wilayah Padang. https://doi.org/10.31227/osf.io/et4rn

Arikunto, Suharsimi. 2010. Prosedur Penelitian Suatu Pendekatan Praktik edisi revisi 2010. Jakarta: PT Rineka Cipta

Fendi, Z., \& Susanti, F. (2018). Pengaruh Kepuasan Kerja Terhadap Turnover Intention Dengan Komitmen Organisasi Sebagai Variabel Intervening Pada CV. Belibis Pariaman. https://doi.org/10.31227/osf.io/wumgx

Hasibuan, Malayu S.P (2001). Dasar, Pengertian dan Masalah Edisi Revisi. Jakarta: Bumi Aksara. 
Junaidi, R., \& Susanti, F. (2019). Pengaruh Gaya Kepemimpinan Dan Budaya Organisasi Terhadap Kinerja Pegawai Pada UPTD Baltekkomdik Dinas Pendidikan Provinsi Sumatera Barat. https://doi.org/10.31227/osf.io/bzq75

Lubis, A. Y. O., \& Susanti, F. (2019). Pengaruh Gaya Kepemimpinan Dan Kompensasi Terhadap Prestasi Kerja Karyawan (Studi pada PT Japfa Comfeed Indonesia (JCI) Tbk Devisi Fam 1. https://doi.org/10.31227/osf.io/7tbrg

Mondy, R Wayne (2008). Manajemen Sumber Daya Manusia. Jakarta : Erlangga

Sedarmayanti (2001). Sumber Daya Manusia dan Produktivitas Kerja. Bandung: Mandar Maju

Ridho, M., \& Susanti, F. (2019). Pengaruh Stres Kerja Dan Motivasi Kerja Terhadap Kepuasan Kerja Pada Karyawan Bank Mandiri Syariah Cabang Padang. https://doi.org/10.31227/osf.io/pa2cg

Siregar, Syofian. 2010. Statistik Deskriptif Untuk Penelitian. Jakarta : Raja Grafindo Persada

Veithzal, Rivai (2005). Manajemen Sumber Daya Manusia untuk Perusahaan. Jakarta: Raja Grafindo Persada

Widodo, Parwato (2004). Pengaruh lingkungan kerja pada hubungan antara kompensasi dan kepemimpinan terhadap kepuasan kerja studi pada kantor pelayanan pajak Salatiga. Salatiga: Kantor Pelayanan Pajak. Dayasaing, 5 (2). pp. 44-52. ISSN 1411-3422. http://eprints.ums.ac.id 3 September 2013

Widodo, B. H., \& Susanti, F. (2019). Pengaruh Human Relation (Hubungan Antar Manusia), Lingkungan kerja Terhadap Etos Kerja karyawan (Studi Kasus Pada PT. Pelindo Teluk Bayur Padang ). https://doi.org/10.31227/osf.io/dxm8a

Yudistira, D. S., \& Susanti, F. (2019). Pengaruh Motivasi Kerja Dan Budaya Kerja Terhadap Kinerja Karyawan Dinas Pemberdayaan Masyarakat Dan Desa, Pengendalian Penduduk Dan Keluarga Berencana Kabupaten Pesisir Selatan. https://doi.org/10.31227/osf.io/jk54m 